\title{
Kedudukan dan Fungsi Badan Nasional Penanggulangan Terorisme (BNPT) Dalam Pemberantasan Terorisme di Indonesia
}

\author{
Nur Paikah \\ Fakultas Syari'ah dan Hukum Islam IAIN Bone \\ Email : Nurpaikah78@gmail.com
}

\begin{abstract}
This study aims to find out and analyze the position and function of the National Counter Terrorism Agency (Badan Nasional Penanggulangan Terorisme/BNPT). This type of research is normative legal research. The approach used is the legislative approach, conceptual approach and case approach.

The results of the study indicate that the BNPT is a non-ministerial state institution under the President and is responsible to the President. In carrying out its duties and functions, BNPT is coordinated with the Coordinating Minister for Politics, Law and Security. The task and function carried out by BNPT is to counter terrorism in Indonesia by using the soft power main approach (prevention). Through a soft power approach BNPT implements two programs, namely deradicalization and counter radicalization. Both of these programs are based on BNPT's view that reducing radicalism does not always have to use a repressive approach as done by the police in general. Law enforcement must be balanced with preventive measures (prevention) by using a pattern of humanitarian approaches so as not to create a sense of revenge and give birth to a new form of violence.
\end{abstract}

Keywords : BNPT; Terrorism; Radicalism

\begin{abstract}
Abstrak
Penelitian ini bertujuan untuk mengetahui dan menganalisis Kedudukan dan fungsi Badan Nasional Penanggulangan Terorisme (BNPT). Tipe penelitian ini merupakan penelitian hukum normatif. Pendekatan yang digunakan yaitu pendekatan perundang-undangan, pendekatan konseptual dan pendekatan kasus.

Hasil penelitian menunjukkan bahwa BNPT berkedudukan sebagai lembaga negara non kementrian yang berada dibawah Presiden dan bertanggungjawab kepada Presiden. Dalam melaksanakan tugas dan fungsinya, BNPT dikoordinasikan dengan Menteri Koordinator Bidang Politik, Hukum, dan Keamanan. Adapun tugas dan fungsi yang diemban oleh BNPT adalah melakukan penanggulangan terorisme di Indonesia dengan menggunakan pendekatan utama soft power (Pencegahan). Melalui pendekatan soft power BNPT melaksanakan dua program yaitu deradikalisasi dan kontra radikalisasi. Kedua program ini didasari oleh pandangan BNPT yang memandang bahwa mereduksi radikalisme
\end{abstract}


Jurnal Al-Adalah: Jurnal Hukum dan Politik Islam

Vol. 4, No. 1, Januari 2019:1-20

P-ISSN: 2406-8802

E-mail: aladalah@iain-bone.ac.id

http://jurnal.iain-bone.ac.id/index.php/aladalah

tidak harus selalu menggunakan pendekatan represif sebagaimana yang dilakukan oleh pihak kepolisian pada umumnya. Penegakan hukum harus diimbangai dengan tindakan preventif (pencegahan) dengan menggunakan pola pendekatan kemanusiaan agar tidak menciptakan rasa dendam maupun melahirkan bentuk kekerasan yang baru.

Kata Kunci: BNPT; Terorisme; Radikalisme

\section{A. Pendahuluan}

Terorisme bukan persoalan siapa pelaku, kelompok dan jaringannya. Namun, lebih dari itu terorisme merupakan tindakan yang memiliki akar keyakinan, doktrin dan ideologi yang dapat menyerang kesadaran masyarakat. Tumbuh suburnya terorisme tergantung di lahan mana ia tumbuh dan berkembang. Jika ia hidup di tanah gersang, maka terorisme sulit menemukan tempat, sebaliknya jika ia hidup di lahan yang subur maka ia akan cepat berkembang. Ladang subur tersebut menurut Hendropriyono adalah masyakarat yang dicemari oleh paham fundamentalisme ekstrim atau radikalisme keagamaan. ${ }^{1}$ Olehnya itu, maka sampai saat ini, terorisme masih menjadi ancaman serius bagi bangsa Indonesia yang dapat memporak-porandakan tatanan berbangsa dan bernegara. Sebagaimana data yang dirilis Global Terrorism Index (GTI) 2016, menyebutkan bahwa dari 129 negera, Indonesia menempati urutan ke 38 negara dengan pengaruh terorisme tertinggi. ${ }^{2}$

Indonesia sebagai salah satu negara dengan pengaruh terorisme tertinggi, tentunya harus menaruh perhatian besar terhadap perkembangan paham radikal serta jaringan terorismes sebab terorisme itu merupakan kejahatan yang bersifat transnasional serta terorganisir dengan kekahasan yang bersifat klandestin ${ }^{3}$, disamping itu kejahatan ini didukung pula oleh pendayagunaan teknologi modern di bidang komunikasi, informatika, transportasi, dan persenjataan modern sehingga tidak mengherankan jika di beberapa negara telah melahirkan sel-sel

\footnotetext{
${ }^{1}$ A.M. Hendroprioyono, Terorisme: Fundamentalis Kristen, Yahudi dan Islam (Jakarta: Buku Kompas, 2009), hlm. 13

${ }^{2}$ https://www.bps.go.id/news/2018/11/08/252/terorisme-mengancam-negara--mariberantas-bersama-.html diakses, Sabtu, 6 Juli 2019

${ }^{3}$ Yang dimaksud dengan klandestin adalah organisasi terorisem memiliki sifat rahasia, diam-diam, atau melakukan gerakan bawah tanah
} 
baru yang menjadi embrio bagi perkembangan jaringan terorisme itu sendiri. Menurut Irfan Idris, pola penyebaran radikalisme dapat dilakukan melalui berbagai saluran, seperti (a) media massa; yang meliputi internet, radio, buku, majalah dan pamphlet; (b) Komunikasi langsung dengan bentuk dakwah, diskusi dan pertemanan; (c) Hubungan keluarga dengan bentuk pernikahan, kekerabatan, dan keluarga inti; dan (d) Lembaga pendidikan, baik di sekolah, pesantren, maupun perguruan tinggi. Diantara pola penyebaran radikalisme tersebut, teknik penyebaran radikalisme melalui media internetlah yang paling sering digunakan. ${ }^{4}$

Kepala Badan Nasional Penanggulangan Teorisme (BNPT) Suhardi Alius, juga mengingatkan bahwa dengan perkembangan teknologi yang begitu pesat, kelompok baru anggota teroris tidak perlu lagi keluar negeri untuk mengenyam pendidikan di Afghanistan, akan tetapi cukup diasa secara intensif melalui media sosial dengan memanfaatkan internet. ${ }^{5}$ Olehnya itu lahir dan berkembangnya selsel baru terorisme di berbagai negara tidak lain karena kemampuan kelompok radikal/teroris dalam memanfaatan konektivitas internet untuk menyasar generasi muda baik kalangan pelajar, mahasiswa atau orang kantoran sebagai target indoktrinisasi.

Melalui konektivitas internet, berbagai konten radikal seperti hakikat jihad dengan mengangkat senjata, tutorial pembuatan bom, tutorial tata cara penggunaan senjata, serta tutorial penyerangan diunggah diberbagai media sosial dan disebar secara masif, terstruktur dan sistematis. Dari konten radikal inilah, seseorang dapat belajar tanpa dibatasi oleh ruang dan waktu yang karena frustasi dengan kondisi sosial yang ada, ia memilih berafiliasi dengan kelompok teroris untuk menebar teror berupa aksi bom bunuh diri dan atau memilih bertindak sendiri dalam melakukan aksi teror tanpa adanya afiliasi atau dukungan dari kelompok teroris manapun dan inilah yang kemudian disebut dengan istilah "self radikalisation”. Disamping itu, terorisme merupakan suatu kejahatan serius yang

\footnotetext{
${ }^{4}$ Irfan Idris, M.A, et.all, 2017, Analisis Isu Kontemporer Modul Pelatihan Dasar Calon CPNS, Lembaga Administrasi Negera RI, Jakarta, hal.68-69

${ }^{5}$ https://nasional.kompas.com/read/2016/09/06/07192151/kepala.bnpt.ungkap.pola.rekrut men.teroris.berubah.karena.internet diakses, Sabtu, 6 Juli 2019
} 
Jurnal Al-Adalah: Jurnal Hukum dan Politik Islam

Vol. 4, No. 1, Januari 2019:1-20

P-ISSN: 2406-8802

E-mail: aladalah@iain-bone.ac.id

http://jurnal.iain-bone.ac.id/index.php/aladalah

dilakukan dengan menggunakan kekerasan atau ancaman kekerasan dengan sengaja, sistematis, dan terencana, yang menimbulkan suasana teror atau rasa takut secara meluas yang target aparat negara, penduduk sipil secara acak atau tidak terseleksi, serta objek vital yang strategis, lingkungan hidup, dan fasilitas publik atau fasilitas internasional dan cenderung tumbuh menjadi bahaya simetrik yang membahayakan keamanan dan kedaulatan negara, integritas teritorial, perdamaian, kesejahteraan dan keamanan manusia, baik nasional, regionai, maupun internasional. ${ }^{6}$

Dengan adanya pola baru dalam perekrutan dan indoktrinisasi anggota kelompok teroris serta adanya rangkaian peristiwa yang melibatkan warga negara Indonesia bergabung dengan organisasi tertentu yang radikal dan telah ditetapkan sebagai organisasi/kelompok teroris, atau organisasi lain yang bermaksud melakukan permufakatan jahat yang mengarah pada Tindak Pidana Terorisme, baik di dalam maupun di luar negeri telah menimbulkan ketakutan masyarakat dan berdampak pada kehidupan politik, ekonomi, sosial budaya, keamanan dan ketertiban masyarakat, ketahanan nasional, serta hubungan internasional. ${ }^{7}$ Maka dengan alasan itupula, terorisme di dunia maupun di Indonesia dapat diibaratkan sebagai "fenomena gunung es" dimana kejahatan tersebut itu bersifat klandestin sehingga yang terlihat hanya pada tataran permukaan saja, yaitu ketika terjadi serangkaian tindakan serangan bom bunuh diri, namun jauh dari pada itu, bahwa didalam lingkungan masyarakat sebenarnya terdapat "sel-sel tidur" terorisme yang sewaktu-waktu negara/pemerintah lengah, "sel tidur" ini dapat menjadi "martir" untuk melakukan serangkaian serangan bom bunuh diri.

\footnotetext{
${ }^{6}$ LIhat penjelasan UU No. 5 Tahun 2018 tentang Perubahan atas UU No. 15 Tahun 2003 tentang Penetapan Peraturan Pemerintah Pengganti UU no. 1 Tahun 2002 tentang Pemberantasan Tindak Pidana Terorisme menjadi UU)

${ }^{7}$ Ibid

8 "Sel tidur" merupakan istilah khas kelompok teroris.Mereka merupakan bagian dari kelompok teroris, tetapi bersembunyi di antara masyarakat. Mereka tidak akan mengumandangkan slogan ISIS setiap hari atau mengibarkan bendera kebanggaannya seperti pada masa kejayaannya dulu. Namun, ketika pimpinan sudah memberikan sinyal, sel-sel tidur itu tidak segan melakukan serangan bunuh diri. Sumber : https://www.jpnn.com/news/sel-tidur-teror-baru-setelah-isisdikubur, diakses, Sabtu 6 Juli 2019
} 
Olehnya itu, melalui tulisan ini penulis mengangkat tema kedudukan dan fungsi BNPT dalam pemberantasan terorisme di Indonesia. Agar pembahasan dalam tulisan ini tidak meluas, maka penulis membatasi tulisan ini dengan batasan masalah sebagai berikut: (1) BNPT; Respon Negara Terhadap satu Dekade Bom Bali 2002 (2) Kedudukan dan Fungsi BNPT dalam Penanggulangan Terorisme.

\section{B. Metode Penelitian}

Tipe penelitian ini adalah penelitian yuridis normatif. Penelitian dilakukan secara kualitatif dengan bertumpu pada studi kepustakaan (library research). Studi kepustakaan merupakan upaya dalam mencari data sekunder antara lain melalui berbagai buku, peraturan perundang-undangan, hasil-hasil penelitian, media cetak dan media elektronik, serta bahan dokumentasi lain yang relevan dengan isu yang dikaji. Dalam penelitian ini, peneliti menggunakan analisis deskriptif kualitatif dengan metode content analysis, yaitu menganalisa data yang diperoleh dari studi kepustakaan terkait peran dan tanggung jawab negara dalam memberantas terorisme.

\section{Pembahasan}

\section{a. BNPT; Respon Negara Terhadap Satu Dekade Pasca Bom Bali 2002}

Pasca Reformasi 1998, Isu terorisme ${ }^{9}$ kembali mengguncang kedaulatan negara kesatuan Republik Indonesia. Berbagai aksi para pelaku terorisme di Indonesia kemudian diidentikkan dengan radikalisme Islam. Hal ini disebabkan karena dari berbagai aksi terorisme yang terjadi di Indonesia selama ini, hampir sebagian besar pelakunya adalah orang atau kelompok orang yang beragama Islam, misalnya Ambrozi bin Hazym, Imam Samudra, Ali Gufron (Mukhlas), Dr. Azhari serta Noordin M Top. ${ }^{10}$ Namun pada 16 Semptember 2009, Jaringan

9 Terorisme adalah perbuatan yang menggunakan kekerasan atau ancaman kekerasan yang menimbulkan suasana teror atau rasa takut secara meluas, yang dapat menimbulkan korban yang bersifat massal, dan/atau menimbulkan kerusakan atau kehancuran terhadap objek vital yang strategis, Iingkungan hidup, fasilitas publik, atau fasilitas internasional dengan motif ideologi, politik, atau gangguan keamanan ( Pasal 1 ayat 2 UU No. 5 TAHUN 2018 tentang Perubahan atas UU No. 15 Tahun 2003 tentang Penetapan Peraturan Pemerintah Pengganti UU no. 1 Tahun 2002 tentang Pemberantasan Tindak Pidana Terorisme menjadi UU)

${ }^{10}$ Ambrozy merupakan pelaku bom Bali 2002 bersama dengan Imam Samudra, namun Imam Samudra selain sebagai pelaku bom Bali 2002, ia juga pernah melakukan pengeboman di 
Jurnal Al-Adalah: Jurnal Hukum dan Politik Islam

Vol. 4, No. 1, Januari 2019:1-20

P-ISSN: 2406-8802

E-mail: aladalah@iain-bone.ac.id

http://jurnal.iain-bone.ac.id/index.php/aladalah

Noordin M.Top dapat dilumpuhkan setelah Noordin M. Top tewas disergap oleh Densus 88 anti teror di daerah Jebres, Solo.

Keberhasilan polri membongkar dan melumpuhkan jaringan teroris Noordin M. Toop pada tahun 2009, serta rutinnya pihak kepolisian dalam melakukan penangkapan serta penggerebekan terhadap seseorang yang diduga menjadi bagian dari kelompok teroris, bukan berarti masyarakat Indonesia telah terbebas dari ancaman terorisme. Tetapi ancaman itu tetap nyata dan tidak bisa diprediksi seperti beberapa rentetan serangan bom bunuh diri yang terjadi di beberapa wilayah Indonesia dari rentan waktu tahun 2011-2018.

Tabel 1

Daftar Serangan Bom Bunuh Diri di Indonesia dari Tahun 2011-2018

\begin{tabular}{lc}
\hline \multicolumn{1}{c}{ Tahun } & Tempat \\
\hline 15 April 2011 & Masjid Az-Dzikra di Mapolresta Cirebon \\
14 Januari 2016 & Kedai Kopi Starbucks, Sarinah Jakarta \\
05 Juli 2016 & Bom di Mapolresta Surakarta, Solo \\
24 Mei 2017 & 2 Bom Meledeak di Terminal Kampung Melayu \\
13 Mei 2018 & 3 Gereja di Surabaya, dan Rusun Wonocolo, Sidoarjo \\
14 Mei 2018 & Mapolresta Surabaya \\
\hline
\end{tabular}

Sumber: Kompas.com ${ }^{11}$

Dari table 1 tersebut dapat dijelaskan bahwa dari rentang waktu tahun 2011-2018 telah terjadi sedikitnya 9 kali serangan bom bunuh diri. Dimulai pada 15 April 2011, serangan bom bunuh diri terjadi di masjid Az-Dzikra Mapolres Cirebon dengan pelaku bernama M. Syarif. Dari aksi pelaku ini setidaknya 25 orang dilaporkan mengalami luka-luka. 5 tahun kemudian, tepatnya 14 Januari

Plaza Atrium tahun 2000, gereja Santa Anna dan Huria Kristen Batak Protestan. Sedangkan Ali Gufron alias Mukhlas merupakan otak pelaku bom Bali 2002. Selain ketiga nama tersebut, ada pula dua nama yang paling top di dunia terorisme asia tenggara, yaitu Dr. Azhari sebagai otak pelaku bom Bali 2002 dan bom Bali 2005 serta Noordin M. Top sebagai orang yang terpandang dikalangan Jamaah Islamiyah (JI) dan bertanggung jawab atas serangkaian aksi teror di Indonesia, dari bom Bali 2002, bom JW Marriot 2003, bom Kedutaan Besar Australia 2004, serta bom JW Marriot dan Ritz-Carlton 2009. Jaringan terorisme Noordin M. Top lah yang paling diburu Polri pada masa Pemerintahan Presiden SBY.

${ }^{11}$ Lutfiah Ayu Azanella, Kompas.com https://nasional.kompas.com/read/2018/05/14/ 13533731/inilah-deretan-aksi-bom-bunuh-diri-di-indonesia?page=all 
2016, serangan bom bunuh diri kembali terjadi di kedai kopi Starbucks, Sarinah Jakarta dengan pelaku berjumlah 5 orang dan menewaskan 2 orang warga sipil serta kelima pelaku. Tak berselang begitu lama, pada 5 Juli 2016, kembali terjadi serangan bom bunuh diri di Mapolresta Surakarta, Solo. Dalam insiden hanya melukai satu anggota polisi, sedangkan pelaku sendiri Nur Rahman dinyatakan tewas dalam menjalankan aksinya. Pada tahun 2017, insiden bom bunuh diri kembali terjadi di dua tempat disekitaran terminal Kampung Melayu, dalam insiden ini dilaporkan bahwa pelaku dan 3 orang anggota polisi dinyatakan meninggal sedangkan 11 orang lainnya mengalami luka-luka. Pada tahun 2018, setidaknya terjadi 5 kali serangan bom bunuh diri. 4 diantaranya terjadi hampir bersamaan pada hari minggu 13 Mei 2018 di 3 buah gereja di Surabaya dan dirusun Wonocolo, Sidoarjo. Dalam insiden ini setidaknya menelan korban jiwa sebanyak 17 orang. Sehari kemudian, Senin, 14 Mei 2018 serangan bom bunuh diri kembali terjadi di Surabaya dengan target Mapolres Surabaya. Dalam Insiden ini pelakunya diketahui dilakukan oleh satu keluarga yang berjumlah 5 orang dimana 4 pelakunya tewas dan seorang lainnya lolos dari maut. ${ }^{12}$

Dari serangkaian serangan bom bunuh diri yang terjadi di beberapa wilayah Indonesia menandakan bahwa aparat penegak hukum kesulitan dalam mencegah aksi terorisme, hal ini dikarenakan serangan bom bunuh diri sewaktuwaktu dapat terjadi dimana pelakunya merupakan bagian dari "sel tidur" kelompok terorisme, dimana aktivitas kesehariannya telah berbaur langsung dengan masyarakat dan sewaktu-waktu dapat melakukan aksi bom bunuh diri sesuai dengan sinyal yang diberikan oleh pimpinannya.

Dari "sel tidur" ini kemudian memberikan kita gambaran bahwa seseorang yang diduga terlibat atau menjadi bagian dari kelompok teroris tentunya tidak terjadi secara instan, namun dibutuhkan suatu proses atau tahapan untuk mendoktrin paham radikal pada diri seseorang sehingga dapat sampai pada keterlibatan dalam aksi terorisme. Maka suksesnya kelompok terorisme dalam indoktrinisasi tergantung dari seberapa jauh paham radikal disemayamkan dalam diri seseorang, sebab tanpa adanya paham radikal yang terdoktrin dalam pikiran

\footnotetext{
12 Ibid
} 
Jurnal Al-Adalah: Jurnal Hukum dan Politik Islam

Vol. 4, No. 1, Januari 2019:1-20

P-ISSN: 2406-8802

E-mail: aladalah@iain-bone.ac.id

http://jurnal.iain-bone.ac.id/index.php/aladalah

seseorang maka akan sulit melakukan aksi teror atau serangan bom bunuh diri.

Dari berbagai penelitian tentang radikalisme dan terorisme, disimpulkan setidaknya ada beberapa cara yang digunakan untuk menjadikan sesorang sebagai terorisme.

Menurut direktur Peace Generation Irfan Amale, cara-cara yang dimaksud yaitu (1) penggunaan narasi politik, yang memandang bahwa telah terjadi ketimpangan dan ketidakadilan yang dipertontonkan oleh penguasa yang kemudian menyasar anak-anak muda untuk terpanggil melakukan jihad. (2) penggunaan narasi historis, dimana pendidikan sejarah itu tidak hanya membangkitkan pengetahuan/kearifan dalam melihat suatu peristiwa/konflik namun dapat pula membangkitkan suatu dendam yang mampu menyulut emosi untuk merebut kembali kejayaan masa lalu (3) Narasi psikologis, yang mengklasifikasikan tokoh-tokoh pelaku kekerasan sebagai pahlawan, (4) instrumental naration yang memandang bahwa kekerasan itu sebagai solusi memecahkan masalah, (5) dan narasi keagamaan yang menggunakan ayat-ayat untuk merekrut anggota baru kelompok. ${ }^{13}$ Sedangkan menurut Abdul Rahman Ayub, berdasarkan pengalamannya sebagai mantan penasehat Jemaah Islamiyah (JI), ia mengklasifikasikan ada tiga tahapan yang diterapkan oleh kelompok radikal di Indonesia (Negara Islam Indonesia atau DII/TII) dalam melakukan indoktrinisasi. Ketiga tahapan tersebut adalah, pertama dengan membangkitkan nostalgia kejayaan islam di era kekhalifaan dan keruntuhan islam, Kedua untuk membangun semangat juang, maka pada tahap selanjutnya adalah menampilkan tontonan kekejaman Yahudi dan Amerika serikat terhadap umat muslim dan negara muslim, invasi Amerika Serikat terhadap Irak dan Afghanistan, dan serta penjara Guantanamo. Dan pada tahap ketiga adalah pendalilan, yaitu menyampaikan dalil-dalil dalam Al-Quran dan hadits sesuai pemahaman mereka untuk menimbulkan keinginan untuk berjihad. ${ }^{14}$

\footnotetext{
${ }^{13}$ Estu Suryowati, Radikalisme Menyusup Ke Dunia Pendidikan, Ini Lima Modusnya, https://nasional.kompas.com/read/2017/05/02/15444221/radikalisme.menyusup.ke.dunia.pendidik an.ini.lima.modusnya. diakses, Jumat 28 Juni 2019

14 Denny Armhandhanu, Tiga Tahap Pola Cuci Otak Kelompok Radikal, https://www.cnnindonesia.com/internasional/20150324141129-106-41446/tiga-tahap-pola-cuciotak-kelompok-radikal. diakses, Jumat, 28 Juni 2019
} 
Berdasarkan uraian tersebut, tentunya seseorang atau kelompok organisasi yang memiliki paham atau keyakinan radikal (radikal dalam pikiran) belum tentu melalukan tindakan radikal pula (radikal dalam aksi/tindakan), sebab ada beberapa tahapan yang harus dilalui. Disamping itu, adapula faktor/ tahapan lain yang menjadikan seseorang berani atau terpaksa bertindak radikal. Secara sosiologis, menurut Noor Huda Ismail, peneliti tentang kekerasan politik mengungkapkan bahwa keterlibatan seseorang sebagai teroris bisa melalui berbagai tangga/ tahapan pergaulan sosial.

1. Tahap pertama, sejumlah individu memiliki keyakinan yang kuat bahwa mereka adalah korban dari ketidakadilan. Mereka kemudian mencoba mencari solusi. Pada saat solusi tidak didapatkan mereka mencoba naik ke tahapan atau tangga berikutnya.

2. Pada tahap kedua, mereka mencoba mengidentifikasi faktor ekternal yang dinilai bertanggung jawab atas ketidak adilan yang mereka hadapi. Mereka yakin bahwa faktor eksternal itu memiliki agenda untuk menghancurkan mereka secara sistematik. Kesimpulan ini memiliki dua implikasi penting. Pertama, mereka adalah orang-orang jelek (bad people), oleh karenanya penggunaan kekerasan terhadap mereka bias dibenarkan (justified). Kedua mereka kemudian diberi label sebagai "evil" (setan) yang berarti menempatkan mereka sebagai subhumans (bukan lagi manusia). Mereka yang berkumpul di tangga kedua ini kemudian berbaur dengan mereka yang memiliki perasaan sama. Mereka kemudian mengarahkan kemarahannya terhadap musuh bersama.

3. Pada tahap ketiga, muncullah ikatan moral kelompok (group's moral bond). Mereka mendiskusikan bagaimana mempersiapkan mental dan fisik sebelum terlibat dalam aktifitas kekerasan fisik terhadap musuh. Diskusi ini dilakukan secara sembunyi. Pimpinan terus menekankan pentingnya loyalitas terhadap organisasi dan berusaha mengisolasi diri dari masyarakat.

4. Proses rekrutmen sesungguhnya terjadi pada tangga atau tahapan keempat. Di sini teroris membagi dunia menjadi dua bagian yang saling 
Jurnal Al-Adalah: Jurnal Hukum dan Politik Islam

Vol. 4, No. 1, Januari 2019:1-20

P-ISSN: 2406-8802

E-mail: aladalah@iain-bone.ac.id

http://jurnal.iain-bone.ac.id/index.php/aladalah

bertentangan yakni mereka versus kami. Mereka hanya mengenal orang yang berada di selnya tidak mengenal sel lain.

5. Pada tahap kelima, anggota yang terpilih dilatih untuk melaksanakan serangan terror. Di sini tidak ada lagi kesempatan atau peluang untuk turun kembali. Mereka menerima perlakuan spesial dari pimpinannya. Misalnya, mereka diberi kesempatan untuk menengok keluarga atau meninggalkan pesan untuk mereka sebagaimana yang dilakukan oleh Dani Dwi Permana. ${ }^{15}$

Tak jauh beda dengan pemikiran Noor Huda Ismail, dalam konseptualisasi pandangan Moghaddam, tindakan terorisme adalah tahap akhir dari pikiran yang semakin menyempit. Dalam kerangka Moghaddam, untuk menjadi terorisme terdapat lima tangga kondisi yang harus dilalui. Pada mulanya, individu menginterpretasikan kondisi materialnya; di tangga pertama, individu mencari solusi tentang apa yang dirasakan sebagai perlakuan yang tidak adil; di tangga kedua, individu membangun kesiapan fisik untuk memindahkan solusi atas persoalan tersebut dengan penyerangan. Mereka yang secara aktif mencari kesempatan untuk melancarkan serangan meningkat pada tahapan selanjutnya, yakni melakukan tindakan melawan pihak-pihak yang dianggap sebagai musuh. Pada tangga ketiga, individu mengidentifikasi diri dengan mengadopsi nilai nilai moral dari kelompoknya. Perkembangan krusial, adalah pada tangga ketiga menuju pada tangga keempat, dimana setelah seseorang memasuki organisasi teroris, dan hanya ada kemungkinan kecil atau bahkan tidak ada kesempatan untuk keluar hidup hidup. Individu dalam tangga kelima ini secara psikologis, menjadi siap dan termotivasi untuk melakukan kegiatan kegiatan terorisme. ${ }^{16}$

Dari hasil uraian diatas, kita dapat memahami bahwa ada beberapa faktor yang mendorong seseorang untuk menjadi bagian dari terorisme dan olehnya itu pulalah Indonesia telah mengambil dan menetapkan kebijakan terkait dengan penanggulangan perkembangan jaringan terorisme. Sebagai langkah progresif negara dalam merespon tindak pidana terorisme yang berkembang pasca

\footnotetext{
${ }^{15}$ Noor Huda Ismail, The Jakarta Post Youth Speak" volume 2, September 2009

${ }^{16}$ Fathali Moghaddam, The Staircase to Terrorisme, American Psychologist, FebruaryMarch, 2005 Vol. 60, No. 2, hl. 161-169
} 
reformasi sebetulnya dipicu dan diawali dari adanya serangan Bom Bali pada tahun 2002, yang mengundang simpatik Dewan Keamanan PBB dengan mengeluarkan resolusi 1438 DK PBB. Pada intinya resolusi 1438 DK PBB adalah mengutuk serangan Bom di Bali, dan menganggap bahwa terorisme merupakan ancaman bagi perdamaian dan keamanan internasional, Disamping itu, juga mengingatkan dan mendesak adanya kerja sama internasional dari negara-negara anggota PBB untuk membantu Indonesia dalam menemukan dan mengadili pelaku, organisasi, dan pihak yang membantu serangan teroris.

Indonesia sebagai negara yang merasakan dampak luar biasa dari aksi terorisme, kemudian merespon resolusi 1438 DK PBB dengan menetapkan kebijakan yang bersifat antisifatif dan proaktof yaitu menerbitkan dua Peraturan Pemerintah Pengganti Undang-Undang (Perppu) pada tahun 2002, yaitu:

a. Perppu Nomor 1 Tahun 2002, tentang Pemberantasan Tindak Pidana Terorisme yang tidak berlaku surut

b. Perpu Nomor 2 Tahun 2002, tentang Pemberlakukan Perppu Nomor 1 Tahun 2002 , tentang Pemberantasan Tindak Pidana Terorisme pada peristiwa peledakan Bom di Bali, tanggal 12 Oktober 2002 yang berlaku surut.

Dengan melihat respon pemerintah yang menerbitkan dua Perppu terkait pemberantasan tindak pidana terorisme tentunya harus memenuhi ketentuan yang yang tertuang didalam Pasal 22 Ayat (1) UUD 1945 yakni adanya "hal ikhwal kegentingan memaksa". Olehnya itu maka, sebagaimana yang tertuang dalam penjelasan Perppu No. 1 Tahun 2002 dapat disimpulkan bahwa alasan mendasar dikeluarkannya Perppu No. 1 Tahun 2002 dan No. 2 Tahun 2002 adalah ; pertama: (1) telah terjadi aksi terorisme di berbagai daerah di Indonesia yang telah menimbulkan kerugian materiil maupun immaterial, dan (b) terjadi berbagai beberapa konflik di beberapa wilayah Indonesia yang sangat merugikan kehidupan berbangsa dan bernegara sehingga moment ini dapat dijadikan tempat yang subur bagi berkembangnya tindak pidana terorisme yang bersifat internasional baik yang dilakukan oleh warga negara Indonesia maupun yang dilakukan oleh orang asing menimbulkan ketidakamanan bagi masyarakat. 
Jurnal Al-Adalah: Jurnal Hukum dan Politik Islam

Vol. 4, No. 1, Januari 2019:1-20

P-ISSN: 2406-8802

E-mail: aladalah@iain-bone.ac.id

http://jurnal.iain-bone.ac.id/index.php/aladalah

Penjelasan pemerintah secara mendalam mengenai Perppu No. 1 Tahun 2002 dipaparkan oleh Romli Atmasasmita yang menyatakan bahwa penyusunan Perppu tersebut memerlukan tidak sekedar justifikasi berupa fakta-fakta sematasemata akan tetapi juga justifikasi filosofis,sosiologis, yuridis, dan teoritis serta konsep-konsep yang berkembang dan berkaitan dengan dengan masalah-masalah terorisme di negara lain. ${ }^{17}$ Sehubungan dengan itu, pemerintah telah menetapkan tiga paradigma yang dipandang cocok dalam konteks kultur politik yang berkembang pada saat itu, yaitu paradima perlindungan kedaulatan wilayah NKRI, perlindungan hak asasi warga negara RI baik didalam maupun diluar negeri, dan perlindungan hak asasi tersangka/terdakwa pelaku tindak pidana terorisme yang sudah merupakan hak universal yang tidak boleh juga diabaikan ${ }^{18}$.

Pada tahun 2003, demi memperkuat landasan hukum dalam pemberantasan tindak pidana terorisme maka pemerintah bersama dengan DPR telah menyepakati dan mansahkan Perppu No. 1 Tahun 2002 menjadi UndangUndang. Maka pada tahun tanggal 3 April tahun 2003 Presiden Megawati Soekarnoputri mensahkan UU No. 15 Tahun 2003 tentang Penetapan Peraturan Pemerintah Pengganti Undang-Undang No. 1 Tahun 2002 tentang Pemberantasan Tindak Pidana Terorisme menjadi Undang-Undang.

Langkah Progresif Pemerintah dalam merespon bahaya dan perkembangan terorisme di Indonesia kemudian di tindak lanjuti dengan menerbitkan Intruksi Presiden Nomor 4 Tahun 2002, yang memberi mandat kepada Menteri Koordinator Bidang Politik dan Keamanan (Menkopolkam) untuk membuat strategi dan kebijakan nasional dalam menangani terorisme. Atas dasar itu pula kemudian Menkopolkam menerbitkan keputusan dengan nomor 26/Menko/Polkam/11/2002 tentang pembentukan Desk Koordinasi Pemberantasan Terorisme (DKPT). Pada tahun 2010, kemudian terjadi sebuah pergeseran pradigma/pendekatan dalam pemberantasan terorisme di Indonesia, yaitu dari dari tindakan represif yang selama ini dilakukan oleh aparat penegak

\footnotetext{
${ }^{17}$ Llhat Romli Atma Sasmita, dalam “Pemberantasan Terorisme Ditinjau dari Aspek Hukum Pidana Internasional, makalah disampaikan dalam kuliah perdana pada Program Pascasarjana UNPAD, di Bandung, tanggal 23 September 2004, hal. 7-8

18 Ibid Hal. 11-12
} 
hukum ke paradigma preventif, yaitu melalui pendekatan kemanusian. Olehnya itu pada tahun 2010, Presiden Susilo Bambang Yudoyono membentuk Badan Nasional Penanggulangan Terorisme (BNPT) yang menggantikan tugas dan kewenangan dari DKPT. Adapun dasar hukum pembentukan BNPT adalah Peraturan Presiden No. 26 Tahun 2010 sebagaimana telah diubah dengan Peraturan Presiden No. 12 tahun 2012 tentang Perubahan atas Peraturan Presiden No. 26 Tahun 2010 tentang Badan Penanggulangan Terorisme.

\section{b. Kedudukan dan Fungsi BNPT dalam Menanggulangi Terorisme}

Indonesia sebagai negara hukum yang demokratis perlu merumuskan suatu kebijakan pencegahan dan pemberantasan terorisme dengan tetap memperhatikan prinsip perlindungan hak asasi manusia dan prinsip kehati-hatian. Olehnya itu maka dalam upaya pencegahan dan pemberantasan terorisme, Indonesia membentuk Badan Nasional Penanggulangan Terorisme (BNPT) pada tahun 2010. BNPT merupakan salah satu lembaga pemerintah non kementrian yang diserahi tugas dan tanggung jawab untuk melakukan penanggulangan terorisme. BNPT berkedudukan dibawah Presiden serta bertanggung jawab kepada Presiden.

Dalam melaksanakan tugas dan fungsinya, BNPT dikoordinasikan Menteri Koordinator Bidang Politik, Hukum, dan Keamanan. Sebagai lembaga pemerintah non kementerian, BNPT dibentuk pada tahun 2010 dengan dasar hukum pembentukannya adalah Peraturan Presiden No. 46 Tahun 2010 tentang Badan Nasional Penanggulangan Terorisme, yang kemudian diperkuat kedudukannya melalui pasal 43E UU No. 5 Tahun 2018 tentang Perubahan atas UU No. 15 Tahun 2003 tentang Penetapan Peraturan Pemerintah Pengganti UU No. 1 Tahun 2002 tentang Pemberantasan Tindak Pidana Terorisme menjadi UU. Sebagai badan yang diserahi kewenangan untuk menanggulangi terorisme, maka BNPT memiliki fungsi ${ }^{19}$ : (a) menyusun dan menetapkan kebijakan, strategi, dan program, nasional di bindang penanggulangan terorisme; (b) Menyelenggarakan kordinasi kebijakan, strategi, dan program nasional di bidang penanggulangan

\footnotetext{
${ }^{19}$ Pasal 43F UU No. 5 Tahun 2018
} 
Jurnal Al-Adalah: Jurnal Hukum dan Politik Islam

Vol. 4, No. 1, Januari 2019:1-20

P-ISSN: 2406-8802

E-mail: aladalah@iain-bone.ac.id

http://jurnal.iain-bone.ac.id/index.php/aladalah

terorisme; (c) melaksanakan kesiapsiagaan nasional, kontra radikalisasi, dan deradikalisasi. Dalam melaksanakan fungsinya, Badan Nasional Penanggulangan Terorisme bertugas: (a) merumuskan, mengoordinasikan, dan melaksanakan kebijakan, strategi, dan program nasional penanggulangan terorisme di bidang kesiapsiagaan nasional, kontra radikalisasi, dan deradikalisasi; (b). mengoordinasikan antarpenegak hukum dalam penanggulangan Terorisme;(c). mengoordinasikan program pemulihan korban; dan (d). merumuskan, mengoordinasikan, dan melaksanakan kebijakan, strategi, dan program nasional penanggulangan Terorisme di bidang kerja sama internasional.

Menurut Kepala BNPT, Suhardi Alius bahwa dalam penanggulangan terorisme di Indonesia pada umumnya dilakukan dengan dua pendekatan, yaitu melalui hard approach atau penindakan yang merupakan kewenangan polri dan soft approach atau pencegahan yang kewenangannya dititik beratkan kepada BNPT. Melalui pendekatan yang kedua ini BNPT memandang bahwa mereduksi radikalisme tidak harus selalu menggunakan pendekatan represif sebagaimana yang dilakukan oleh pihak kepolisian pada umumnya. Penegakan hukum harus diimbangai dengan tindakan preventif (pencegahan) yang menggunakan pola pendekatan kemanusiaan agar tidak menciptakan rasa dendam maupun melahirkan bentuk kekerasan yang baru. Olehnya itu dalam pendekatan soft approach ini, ada dua program yang dijalankan oleh BNPT, yaitu melalui program deradikalisasi dan kontra radikalisasi.

\section{Deradikalisasi}

Menurut Hamidin selaku Direktur Pencegahan Badan Nasional Penanggulangan Terorisme (BNPT), deradikalisasi adalah program yang bertujuan untuk menetralkan pemikiran-pemikiran bagi mereka yang sudah terpapar dengan radikalisme dengan sasaran utama adalah para terorisme baik yang berada didalam lembaga pemasyarakatan (lapas) maupun yang ada diluar lapas. Adapun tujun dari deradikalisasi ini adalah membersihkan pemikiranpemikiran radikalisme yang ada pada mereka sehingga mereka bisa kembali 
menjadi masyarakat biasa sebagaimana masyarakat lainnya atau mentralisir pemikiran radikal agar tidak radikal lagi ${ }^{20}$.

Deradikalisasi dalam pemahaman SETARA Institute adalah mendeteksi secara dini, menangkal sejak awal, dan menyasar berbagai lapisan potensial dengan beragam bentuk dan varian yang relevan bagi masing-masing kelompok yang menjadi sasaran. Tujuan utama dari deradikalisasi, bukan hanya mengikis radikalisme, memberantas potensi terorisme tapi yang utama adalah mengokohkan implementasi empat pilar hidup berbangsa dan bernegara untuk mencapai tujuan dan cita-cita nasional Indonesia ${ }^{21}$. Pasal 43 D ayat 1 UU No. 5 Tahun 2018 mendefinisikan deradikalisasi sebagai suatu proses yang terencana, terpadu, sistematis dan berkesinambungan yang dilaksankan untuk menghilangkan atau mengurangi dan membalikkan pemahaman radikal terorisme yang telah terjadi. Adapun program deradikalisasi ini ditujukan kepada (a) tersangka; (b) terdakwa; (c) teridana; (d) narapidana; (e) mantan narapidana terorisme; atau (f) orang atau kelompok orang yang sudah terpapar paham radikal terorisme.

Dengan melihat sasaran dari program deradikalisasi, maka dalam pelaksanaannya terdapat perbedaan tahapan yang diberikan kepada orang yang berstatus tersangka, terdakwa, terpidana dan atau narapidana dengan mantan narapidana terorisme atau orang/ kelompok orang yang sudah terpapar paham radikal terorisme. Bagi orang yang berstatus tersangka, terdakwa, terpidana dan atau narapidana, deradikalisasi diberikan melalui beberapa tahapan yaitu: pada tahapan pertama dilakukan identifikasi dan penilaian; dimana pada tahapan ini merupakan penggambaran secara rinci tingkat keterpaparan seseorang mengenai peran atau keterlibatannya dalam kelompok atau jaringan sehingga dapat diketahui tingkat radikal terorismenya. (2) Tahapan kedua rehabilitasi; pada tahapan ini dilakukan proses pemulihan dan penyembuhan untuk menurunkan tingkat radikal terorisme seseorang (3) reedukasi; pada tahap ini dilakukan

20 https://www.bnpt.go.id/direktur-pencegahan-bnpt-siapa-bilang-deradikalisasi gagal. html

${ }^{21}$ Tim SETARA Institute, 2012, Dari Radikalisme Menuju Terorisme Studi Relasi dan Transformasi Organisasi Islam Radikal di Jawah Tengah dan D.I Yogyakarta, Jakarta, Pustaka Masyarakat Setara, hal. 3 
Jurnal Al-Adalah: Jurnal Hukum dan Politik Islam

Vol. 4, No. 1, Januari 2019:1-20

P-ISSN: 2406-8802

E-mail: aladalah@iain-bone.ac.id

http://jurnal.iain-bone.ac.id/index.php/aladalah

pembinaan atau penguatan kepada seseorang agar meninggalkan paham radikal terorisme dan (4). reintegrasi sosial, serangkaian kegiatan yang dilakukan untuk mengembalikan orang yang terpapar paham radikal terorisme agar dapat kembali kedalam keluarga dan masyarakat.

Sedangkan bagi mantan terpidana terorisme maupun orang atau kelompok orang yang sudah terpapar paham radikal terorisme, program deradikalisasi dilaksanakan melalui kegiatan (a) pembinaan wawasan kebangsaan, (b) pembinaan wawasan keagamaan, dan (c) kewirausahaan. Namun perlu digarisbawahi bahwa deradikalisasi dengan melalui kegiatan pembinaan wawasan kebangsaan dan keagamaan, serta pelatihan kewirausahaan tetap didasarkan pada identifikasi dan penilaian.

Sebagai program yang dicanangkan oleh BNPT dalam menanggulangi terorisme, Irfan Idris Direktur Deradikalisasi BNPT mengemukakan bahwa ada 4 jenis pendekatan dalam desain deradikalisasi di Indonesia, yaitu: Reedukasi, Rehabilitasi, Resosialisasi, dan Reintegrasi. Reedukasi adalah penangkalan dengan mengajarkan pencerahan kepada masyarakat tentang paham radikal, sehingga tidak terjadi pembiaran berkembangnya paham tersebut. Sedangkan bagi narapidana terorisme, reedukasi dilakukan dengan memberikan pencerahan terkait dengan doktrin-doktrin menyimpang yang mengajarkan kekerasan sehingga mereka sadar bahwa melakukan kekerasan seperti bom bunuh diri bukanlah jihad yang diidentikkan dengan aksi terorisme. ${ }^{22}$

Rehabilitasi memiliki dua makna, yaitu pembinaan kemandirian dan pembinaan kepribadian, pembinaan kemandirian adalah melatih dan membina para mantan napi mempersiapkan keterampilan dan keahlian, gunanya adalah agar setelah mereka keluar dari lembaga pemasyarakatan, mereka telah memiliki keahlian dan bisa membuka lapangan pekerjaan. Sedangkan pembinaan kepribadian adalah melakukan pendekatan dengan berdialog kepada para napi teroris agar mind set mereka bisa diluruskan serta memiliki pemahaman yang komprehensif serta dapat menerima pihak yang berbeda dengan mereka. Proses

${ }^{22}$ Mochamad Nurhuda Febriyansah dkk, Upaya Deradikalisasi Narapidana Terorisme di Lembaga Pemasyarakatan (Lapas) Kedung Pane Semarang, Jurnal. Seminar Nasional Hukum Universitas Negeri Semarang Volume 3 Nomor 1 Tahun 2017, hal 95-96 
rehabilitasi dilakukan dengan bekerjasama dengan berbagai pihak seperti polisi, Lembaga Pemasyarakatan, Kementerian Agama, Kemenkokesra, ormas, dan lain sebagainya. Diharapkan program ini akan memberikan bekal bagi mereka dalam menjalani kehidupan setelah keluar dari lembaga pemasyarakatan. ${ }^{23}$

Selain program terebut, untuk memudahkan mantan narapidana dan narapidana teroris kembali dan berbaur ke tengah masyarakat, BNPT juga mendesain program resosialisasi dan reintegrasi, dengan cara membimbing mereka dalam bersosialisasi dan menyatu kembali dengan masyarakat. Selain itu deradikalisasi juga dilakukan melalui jalur pendidikan dengan melibatkan perguruan tinggi, melalui serangkaian kegiatan seperti public lecture, workshop, dan lainnya, mahasiswa diajak untuk berfikir kritis dan memperkuat nasionalisme sehingga tidak mudah menerima doktrin yang destruktif. ${ }^{24}$ Namun sebagai sebuah program yang dicanangkan dalam mengubah mind set seseorang agar tidak bertindak radikal layaknya sebagai teroris, tentunya masih memiliki kelemahan dan harus diperhatikan oleh pemerintah. Deradikalisasi dalam implementasinya hanya sampai pada tataran mengubah prilaku dan radikal menjadi tidak radikal, padahal seyogyanya adalah menyentuh hal yang paling urgen yaitu menghapus atau menghilangkan doktrin radikal dalam diri seseorang. Dan inilah yang harus diwaspadai oleh pemerintah jangan sampai hanya menghasilkan out put yang menjadi bagian dari "sel tidur" terorisme itu sendiri.

\section{Kontra Radikalisasi}

Berbeda dengan deradikalisasi yang fokus programnya ditujukan kepada orang atau kelompok orang yang telah terpapar paham radikal terorisme. Program kontra radikalisasi lebih ditujukan kepada orang atau kelompok orang yang rentan akan terpapar paham radikal terorisme. Pasal $43 \mathrm{C}$ ayat 1dan 2 UU No. 5 tahun 2018 menjelaskan bahwa kontra radikalisasi merupakan suatu proses yang terencana, terpadu, sistematis, dan berkesinambungan yang dilakukan oleh pemerintah dengan dikoordinasi oleh BNPT serta melibatkan kementerian atau lembaga terkait, yang mana kontra radikalisasi ini dilaksanakan dengan maksud

\footnotetext{
${ }^{23}$ Ibid

${ }^{24}$ Ibid
} 
Jurnal Al-Adalah: Jurnal Hukum dan Politik Islam

Vol. 4, No. 1, Januari 2019:1-20

P-ISSN: 2406-8802

E-mail: aladalah@iain-bone.ac.id

http://jurnal.iain-bone.ac.id/index.php/aladalah

untuk menghentikan penyebaran paham radikal terorisme sehingga kegiatan ini lebih ditujukan terhadap orang atau kelompok orang yang rentan terpapar paham radikal terorisme. Adapun terkait dengan pelaksanaan kontra radikalisasi ini dapat dilakukan baik secara langsung maupun tidak langsung melalui kontra narasi, kontra propaganda, atau kontra ideologi. ${ }^{25}$

Hal ini harus menjadi perhatian serius dari pemerintah terutama BNPT sebab sebagaimaa telah diuraikan diawal tulisan ini bahwa media internet menjadi media maen stream dalam menyebarkan paham radikal terorisme sebab menurut Sujatmiko, Kepala Kasubdit Kontra Propaganda BNPT terorisme tidak hanya dipandang sekedar aksi, tetapi yang lebih berbahaya adalah narasi. Sementara penyebaran narasi radikal terorisme saat ini tumbuh dengan subur di dunia maya olehnya itu sebagai langkah BNPT dalam melakukan kontra radikalisasi adalah dengan membuat website damailahindonesia.com yang berisi berbagai narasi untuk mencounter paham radikal, disamping itu dilakukan berbagai pelatihan dalam merekrut dan membentuk duta damai dunia maya, seperti yang telah dilakukan di beberapa daerah seperti Sumatra Utara, Sulawesi Selatan, DKI Jakarta, DI Yogyakarta, Jawa Barat, Jawa Tengah, Jawa Timur, Sumatera Barat, Kalimantan Selatan dan Nusa Tenggara Barat. Dari pelaksanaan kegiatan tersebut, telah berhasil membentuk 53 kelompok duta damai dunia maya di 10 provinsi dengan jumlah anggota 660 orang. ${ }^{26}$

\section{Kesimpulan}

Perkembangan jaringan terorisme dalam suatu negara semakin sulit dibendung. Hal ini disebabkan karena adanya dukungan dari teknologi informasi dan komunikasi yang begitu pesat sehingga membawa pula dampak bagi perubahan pola perekrutan anggota baru teroris. Dengan hanya menggunakan

\footnotetext{
${ }^{25}$ Yang dimaksud dengan kontra narasi, kontra propaganda, dan kontra ideology yaitu berbagai upaya untuk melawan paham radikal terorisme dalam bentuk lisan, tulisan dan media literasi lainnya.

${ }^{26}$ Agus Gombol, Duta Damai Banten Siap Usung Perdamaian di Dunia Maya” https://damailahindonesiaku.com/duta-damaibanten-siap-usung-perdamaian-di-dunia-maya. html ,diakses 16 Juli 2019
} 
konektivitas internet, anggota baru teroris sewaktu-waktu dapat saja direkrut dengan melakukan indoktrinisasi secara instens di media sosial. Namun dari perekrutan tersebut bukan berarti seseorang langsung menjadi terorisme, namun diperlukan tahapan panjang yang mesti dilalui ntuk menjadi teroris. Menyadari akan bahaya yang ditimbulkan oleh terorisme pasca tragedi Bom Bali 2002, kemudian negara merespon dengan langka yang bersifat antipatif dan proaktif negara menerbitkan dua Peratutan Pemerintah Pengganti Undang-Undang (Perppu) yang kemudian disusul dengan pembentukan Desk Kordinasi Pemberantasan Terorisme tahun 2002, dan kemudian pasca satu dekade Bom Bali 2002 kemudian Presiden menerbitkan Peraturan Presiden No 46 Tahun 2010 yang kemudian menjadi dasar lahirnya BNPT. Sebagai lembaga yang dibentuk menanggulangi terorisme, BNPT dalam melaksanakan tugas dan fungsinya menggunakan dua jenis program yaitu deradikalisasi dan kontra radikalisasi.

\section{Daftar Pustaka}

Febriyansah, Mochamad Nurhuda dkk, Upaya Deradikalisasi Narapidana Terorisme di Lembaga Pemasyarakatan (Lapas) Kedung Pane Semarang, Jurnal. Seminar Nasional Hukum Universitas Negeri Semarang Volume 3 Nomor 1 Tahun 2017

Hendroprioyono. A.M.2009, Terorisme: Fundamentalis Kristen, Yahudi dan Islam, Jakarta: Buku Kompas

Idris, Irfan, et.all, 2017, Analisis Isu Kontemporer Modul Pelatihan Dasar Calon CPNS, Jakarta . Lembaga Administrasi Negera RI.

Ismail, Noor Huda, The Jakarta Post Youth Speak" volume 2, September 2009

Moghaddam, Fathali, The Staircase to Terrorisme, American Psychologist, February- March, 2005 Vol. 60, No. 2

Tim SETARA Institute, 2012, Dari Radikalisme Menuju Terorisme Studi Relasi dan Transformasi Organisasi Islam Radikal di Jawah Tengah dan D.I Yogyakarta, Jakarta, Pustaka Masyarakat Setara.

Wawan H. Purwanto, 2004, Terorisme Ancaman Tiada Akhir, Jakarta, Grafindo

Undang-Undang No. 5 Tahun 2018 tentang Perubahan atas Undang-Undang No. 15 Tahun 2003 tentang Penetapan Peraturan Pemerintah Pengganti Undang-Undang No. 1 Tahun 2002 tentang Pemberantasan Tindak Pidana Terorisme menjadi Undang-Undang (Lembaran Negara Republik Indonesia Tahun 2018 Nomor 92, Tambahan Lembaran Negara Republik Indonesia Nomor 6216). 
Jurnal Al-Adalah: Jurnal Hukum dan Politik Islam

Vol. 4, No. 1, Januari 2019:1-20

P-ISSN: 2406-8802

E-mail: aladalah@iain-bone.ac.id

http://jurnal.iain-bone.ac.id/index.php/aladalah

Estu Suryowati, Radikalisme Menyusup Ke Dunia Pendidikan, Ini Lima Modusnya,https://nasional.kompas.com/read/2017/05/02/15444221/radikal isme.menyusup.ke.dunia.pendidikan.ini.lima.modusnya. diakses, Jumat 28 Juni 2019.

Denny Armhandhanu, Tiga Tahap Pola Cuci Otak Kelompok Radikal, https://www.cnnindonesia.com/internasional/20150324141129-10641446/tiga-tahap-pola-cuci-otak-kelompok-radikal

Kompas.com https://nasional.kompas.com/read/2018/05/14/13533731/inilahderetan-aksi-bom-bunuh-diri-di-indonesia?page=all diakses, Jumat, 28 Juni 2019

https://www.bps.go.id/news/2018/11/08/252/terorisme-mengancam-negara--mariberantas-bersama-.html diakses, Sabtu, 6 Juli 2019

https://nasional.kompas.com/read/2016/09/06/07192151/kepala.bnpt.ungkap.pola. rekrutmen.teroris.berubah.karena.internet diakses, Sabtu, 6 Juli 2019

https://www.jpnn.com/news/sel-tidur-teror-baru-setelah-isis-dikubur, diakses, Sabtu 6 Juli 2019

https://www.bnpt.go.id/direktur-pencegahan-bnpt-siapa-bilang-deradikalisasi gagal. html 